\title{
To Intervene or Not to Intervene: Ethics of Humanitarian Intervention in Myanmar
}

\section{Dr Imran Syed}

\begin{abstract}
The Rohingya, sometimes referred to as the 'most persecuted people in the world', in 2017, once again, faced violence in Myanmar and many have been forced into displacement across international borders. More recently, in August 2018, they were in the spotlight as they observed the 'anniversary' of the spate of mass displacements. The violence faced by this group is of extreme proportions and has persisted over many decades. This article examines the issue of the Rohingya of Myanmar from the lens of global ethics and International Relations. The solution to this humanitarian crisis does not seem to be coming from inside the borders of the country. From outside, there exists the possibility of international intervention on humanitarian grounds. The article explores a possible framework for such an intervention by examining interests of the intervening states and those of the people of the intervened state.
\end{abstract}

Keywords: Humanitarian Intervention, Ethics, Refugees, Rohingya, Myanmar, Ethnic Nationalism, Minority Rights.

* The author is Head of the Centre for Policy Studies (CPS), COMSATS University Islamabad, Pakistan. He can be reached at: imran.syed@comsats.edu.pk.

@ 2019 by the Islamabad Policy Research Institute.

IPRI Journal — XIX (1): 111-127.

https://doi.org/10.31945/iprij.190105.

IPRI JOURNAL — WINTER 2019 


\section{Introduction}

$\mathrm{F}$ or the Rohingya refugees in the camps of Cox Bazar, Bangladesh, August 25, 2018, was a day of painful memories, protest and prayers. It marked the first anniversary of the beginning of a year that saw the destruction of property, rape, murder and led to the forced displacement of over 700,000 Rohingya to Bangladesh. ${ }^{1}$ The label of being 'the most persecuted people in the world' ${ }^{2}$ reflects the extreme and extended suffering of these people.

The nature of violence against the Rohingya has a history that predates the creation of Myanmar. There have been incidents in 1926, 1930 and 1938 of primarily Buddhist groups involved in violence against communities that had South Asian characteristics like the Rohingya. ${ }^{3}$ Their predicament started to decidedly change from 1962 after the military came into power. Since that time, their status and conditions have, in many ways, worsened. Importantly, the constitution of 1974 revised the status that had been accorded to them at the time of independence. Now, they were re-classified as 'Foreigners' in the identification cards. The 1982 Citizenship Law gave citizenship status to those having lived in Myanmar since 1824, ${ }^{4}$ effectively, making this IndoAryan ethnic group 'stateless' people. This statelessness is a major factor exacerbating their suffering. The United Nations High Commissioner for

${ }^{1}$ Zeba Siddiqui, "Anniversary of Rohingya Crisis Marked in Bangladesh Camps, Myanmar," Reuters, August 25, 2018, https://www.reuters.com/article/us-myanmarrohingya-anniversary/anniversary-of-rohingya-crisis-marked-in-bangladesh-campsmyanmar-idUSKCN1LA0HX.

2 Angela Dewan, "Who are the Rohingya and Why are They Fleeing?" CNN.com, September 13, 2017, http://edition.cnn.com/2017/09/05/asia/rohingya-myanmarexplainer/index.html; A. A. Gill, "Robbed, Raped, Killed: The Most Persecuted People on Earth," Sunday Times, November 26, 2017, https://www.thetimes.co.uk/article/robbed-raped-killed-the-most-persecuted-people-onearth-5dhcmgp8w; and "The Most Persecuted People on Earth?" Economist, June 13, 2015, https://www.economist.com/news/asia/21654124-myanmars-muslim-minorityhave-been-attacked-impunity-stripped-vote-and-driven.

3 Peter Coclanis, "Terror in Burma: Buddhist vs. Muslims," World Affairs 176, no. 4 (2013): 25-33 (30).

4 Azeem Ibrahim, The Rohingyas: Inside Myanmar's Hidden Genocide (London: Hurst and Co. Publishers, 2016), 8. 
Refugees (UNHCR) estimated that by the end of 2015, this 'stateless' population numbered around $938,000 .^{5}$

The state of being without a nationality poses an extraordinary set of problems and vulnerabilities. These problems become even more critical because the condition of statelessness does not provide access to public mechanisms such as courts, the police, healthcare, etc. It is also a contributing factor for involvement in the drug trade, human trafficking and other forms of slavery. The desperation of the 'stateless' can become a catalyst for a violent reaction. ${ }^{6}$

The 1990s saw a movement against the military and in support of democracy in Myanmar. This movement fed into a countermovement by the military regimes to draw the Buddhist monks away from the antigovernment activities in a 'Buddhist renewal movement' that combined the Buddhist religious sentiment with ethnic nationalism, ${ }^{7}$ made more complicated through intersections with race, religion and economics. The Rakhine is one of the poorest areas in Myanmar and the backwardness of this region fuels a narrative of the Rohingya being 'backward' and an allied narrative of the 'superiority' of the Buddhist of Rakhine. ${ }^{8}$

This issue needs attention because it is an intractable one that has remained unsolved for over 70 years, and thus, will not solve itself without special attention. The recent flare-up led the Office of High Commissioner for Human Rights (OHCHR), in September 2017, to term the violence against the Rohingya as a 'textbook example of ethnic cleansing. ${ }^{9}$ According to the UNHCR, as of November 22, 2017, the

5 UNHCR, UNHCR Statistical Yearbook 2015 (Geneva: United Nations High Commissioner for Refugees, 2017), 8, http://www.unhcr.org/statistics/country/59b294387/unhcr-statistical-yearbook-201515th-edition.html.

${ }^{6}$ Bill Berkeley, "Stateless People, Violent States," World Policy Journal 26, no. 1 (2009): 3-15, https://doi.org/10.1162/wopj.2009.26.1.3.

7 Coclanis, "Terror in Burma: Buddhist vs. Muslims," 25-26.

8 Ibrahim, The Rohingyas: Inside Myanmar's Hidden Genocide, 9.

9 Ben Westcott and Karen Smith, "Rohingya Violence a 'Textbook Example of Ethnic Cleansing,' UN Rights Chief Says," CNN.com, September 11, 2017, http://edition.cnn.com/2017/09/11/asia/rohingya-un-ethnic-cleansing/index.html. 
Rohingya refugees who fled to Bangladesh in almost three months, numbered $624,000 .^{10}$

In addition to the divisions between the Rohingya and nonRohingya communities living in Myanmar along religion, language, and ethnicity, there are also aspects of race that fuel the divide. The South Asian features of the Muslims in Myanmar contrast with the East Asian characteristics of the mostly Buddhist Bamar. ${ }^{11}$ The Rohingya are mainly concentrated in Northern Arkan or Rakhine state, and speak and look like the Bengalis of Chittagong. These characteristics set them apart from the Buddhist of South East Asian descents who speak Burmese. They are restricted from travelling both inside and outside the country, are required to obtain legal permission before they can marry (the authorisation usually takes several years to obtain), have restrictions on how many children they can bear, and on accessing public health and educational services. ${ }^{12}$

This article recognises the complexity of the situation in which the Rohingya are situated by acknowledging that attempts at a solution have to be multifaceted and have to, at the least, address both the political and moral aspects. Hans Morgenthau, an important thinker in International Relations (IR), wrote in 1948 that one must never forget 'that the complexities of international affairs make simple solutions and trustworthy prophesies impossible. ${ }^{, 13}$ The pursuit of a multifaceted and cross-disciplinary inquiry is also supported by the view that globalisation generally fosters a need for multidisciplinary research to address matters that in the past could have been effectively handled within disciplinary boundaries. The examination of literature on humanitarian intervention finds much work done of a theoretical nature with a focus on the competing norms of sovereignty on the one hand, and humanitarian

\footnotetext{
${ }^{10}$ United Nations High Commissioner for Refugees, Rohingya Emergency, accessed February 14, 2019, http://www.unhcr.org/rohingya-emergency.html.

${ }^{11}$ Coclanis, "Terror in Burma: Buddhist vs. Muslims," 30.

${ }^{12}$ Chris Lewa, "North Arakan: An Open Prison for the Rohingya in Burma," Forced Migration Review, no. 32 (2009): 11-13 (11-12), https://www.fmreview.org/sites/fmr/files/FMRdownloads/en/FMRpdfs/FMR32/FMR32. pdf.

${ }^{13}$ Hans Joachim Morgenthau, Politics among Nations: The Struggle for Power and Peace (New York: Alfred A. Knopf, 1948), 6
} 
concerns, on the other. There is research that focuses on this divide - some taking a philosophical view, some a political one and others a historical focus. ${ }^{14}$ There is also significant scholarship to be found that combines the theoretical with a study of a case or several cases of international humanitarian intervention. ${ }^{15}$ However, a review of the available literature did not find scholarship that explores humanitarian intervention looking at IR, global ethics and issues of the Rohingya of Myanmar in the same manner as is being done in this article.

\section{Context and Framework for Analysis}

The plight of the Rohingya has compound foundations that predate the independence of Myanmar (then Burma) in 1948. The complexity comes from a violence-ridden interplay of identity, religion and politics, extending over many decades. The recent iteration of the Rohingya crisis escalated in 2017 , and garnered international media coverage in the wake of large-scale atrocities and subsequent forced mass displacement of their population across international borders. This crisis is not only an issue that is very much internal to the Myanmar state, it is also one that has international implications.

\footnotetext{
${ }^{14}$ Jean L. Cohen, "Rethinking Human Rights, Democracy and Sovereignty in the Age of Globalization," Political Theory 36, no. 4 (2008): 578-606;

Sigrun Skogly and Mark Gibney, "Transnational Human Rights Obligations," Human Rights Quarterly 24, no. 3 (2002): 781-798, DOI:10.1353/hrq.2002.0040;

Mohammed Ayoob, "Humanitarian Intervention and State Sovereignty," The International Journal of Human Rights 6, no. 1 (2002): 81-102, https://doi.org/10.1080/714003751;

Kelly Kate Pease and David P. Forsythe, "Human Rights, Humanitarian Intervention, and World Politics," Human Rights Quarterly 15, no. 2 (1993): 290-314, DOI: 10.2307/762540; and Caroline Thomas, "Human Rights and Intervention: A Case for Caution," Irish Studies in International Affairs 5 (1994): 15-28.

${ }^{15}$ Ricardo Soares de Oliveira and Harry Verhoeven, "Taming Intervention: Sovereignty, Statehood and Political Order in Africa," Survival: Global Politics and Strategy 60, no. 2 (2018): 7-32, https://doi.org/10.1080/00396338.2018.1448558; and Nicholas Idris Erameh, "Humanitarian Intervention, Syria and the Politics of Human Rights Protection," The International Journal of Human Rights 21, no. 5 (2017): 517530, https://doi.org/10.1080/13642987.2017.1307829.
} 
On the political landscape of Myanmar, the 1962 martial law imposed by General Win figures prominently. The martial law was followed by a foreign policy of isolationism. In 1988, the government crushed a pro-democracy movement and once again directly controlled the country. The non-democratic governments and the human rights violations in Myanmar have been opposed by the West. This is reflected in the international support, over the years, for ending the restrictions and incarceration of Aung San Suu Kyi, one of the leaders of the movement. The world expected that Suu Kyi would be instrumental in resolving the problems faced by the Rohingya on a political basis. She had credentials that supported these expectations, given that she spent nearly two decades in confinement, and her politics was in opposition to the non-democratic dictatorial regimes of Myanmar. The restrictions on Suu Kyi were eased in 2002, ${ }^{16}$ but her support for a political solution of the Rohingya crisis since then has disappointed many. Her lack of outrage at their persecution has lend credence to the view that she and the National League for Democracy (NLD) while supporting democracy, like the autocratic regimes of the past and the Burmese elite in general, do not support the case of the Rohingya. ${ }^{17}$

Involvement of the international community in the resolution of this issue is driven in part because a solution from inside Myanmar does not seem forthcoming. International political consideration is of consequence since Myanmar lies at the juncture of South, South East and East Asia. Its geostrategic importance is further highlighted as it is situated between the two major regional countries: India and China. Myanmar also shares borders with Bangladesh, Laos and Thailand. From an international affairs perspective, the international actors, both bilateral and multilateral, that are influential (or interested in being more influential) in Myanmar include the United Nations (UN), Association of Southeast Asian Nations (ASEAN), the United States of America (USA), Russia, the European Union (EU), India, Bangladesh and China. These international actors have influenced the regimes in Myanmar, at different times and to differing

\footnotetext{
${ }^{16}$ David I. Steinberg "Myanmar: Reconciliation- Progress in the Process," Southeast Asian Affairs (2003): 171-188 (171).

17 Ibrahim, The Rohingyas: Inside Myanmar's Hidden Genocide, 2.
} 
extents. One ostensible dichotomy that has been seen in the international politics as it relates to Myanmar is that moral admonishment for mistreatment of the Rohingya has been accompanied by a general tolerance for the regimes that have perpetuated it. Generally, their mistreatment has been viewed as morally indefensible, but has not elicited an international humanitarian intervention. The extensive and protracted involvement of international actors, coupled with the complexity of international alliances and balance of power, has served to constrict action of a humanitarian nature and has pushed support for maintaining the status quo. ${ }^{18}$

The idea of a humanitarian intervention in a state from other states is usually debated around two competing concerns:

1. international norms of national sovereignty; and,

2. humanitarian needs of the population suffering within the state.

In a globalised present, with varying extents of multifaceted interdependence between countries, institutions and peoples, the concept of intervention needs to be examined with care. Also, there needs to be recognition that in the present interdependent world, there are many extents and areas in which one state can intervene in the affairs of another, such as economic sanctions, military intervention, peacekeeping operations, etc. This article will be looking at an intervention in the internal affairs of a state, that is overt, that is based on humanitarian reasoning, is backed by military support (which may be multilateral), and that, for the most part, will not be welcomed by the government of the state that is being intervened into.

The nature of humanitarian intervention in states has been justified using various combinations of political and moral arguments. The present is also complicated by examples of both non-intervention and examples of humanitarian intervention. This article will not focus on analysing the many different debates about when a humanitarian intervention is justified or not justified. Generally, the moral justification to not intervene rests largely on the need for maintaining an order in the global society and thus,

${ }^{18}$ Ibid., 164-167. 
foreign intervention is seen to lead to conflict and instability. ${ }^{19}$ Against reasons not to intervene, stand moral reasons that justify humanitarian intervention. Though there is much debate on the appropriate framework to use in justification of an intervention, this study does not look at an exhaustive evaluation of competing frameworks for justifying intervention. It does, however, recognise that some frameworks appear to have been widely embraced by the international community, such as the Responsibility to Protect (R2P). ${ }^{20}$ Still, ostensibly popular frameworks, such as R2P which was approved by the UN General Assembly in 2005, have also had limited success in addressing humanitarian interventions. ${ }^{21}$ The study takes a position that the framework, that will better address the matter of humanitarian intervention, is one that seeks to combine the practical concerns of international politics driven by interests with concerns that are driven by morals, a combination that many potential frameworks, such as R2P, seem to be lacking. ${ }^{22}$ In doing so, this article progresses the inquiry on intervention along an ostensibly parsimonious proposition that posits that a humanitarian intervention finds support if it is in the interest of the intervening states, and if the intervention is in the interest of the people of the intervened state. ${ }^{23}$

Some IR scholars have concluded that, historically, it appears that a powerful motivation for interventions by states in other states has been the advancement of the goals or interests of the intervening state. ${ }^{24}$ This thinking is very much in alignment with the Realist school of IR according to which states are motivated by self-interest: use of power to promote one's interest is justified and is what relations between states is

\footnotetext{
${ }^{19}$ Mark R. Amstutz, International Ethics: Concepts, Theories and Cases in Global Politics, 4th ed. (Lanham: Rowman and Littlefield Publishers, 2013), 182.

${ }^{20}$ Melinda Negron-Gonzales and Michael Contarino, "Local Norms Matter: Understanding National Responses to the Responsibility to Protect," Global Governance 20, no. 2 (2014) 255-276 (256), DOI: 10.1163/19426720-02002006.

${ }^{21}$ E. C. Luck, "R2P at Ten: A New Mindset for a New Era?" Global Governance 21, no. 4 (2015) 499-504, DOI: 10.1163/19426720-02104001.

${ }^{22}$ Christof Royer, "Framing and Reframing R2P - A Responsibility to Protect Humanity from Evil," Critical Review of International Social and Political Philosophy (2018): 121 (1-2), https://doi.org/10.1080/13698230.2018.1479818.

${ }^{23}$ Amstutz, International Ethics: Concepts, Theories and Cases in Global Politics, 194.

${ }^{24}$ Ibid., 185.
} 
all about. However, there is a difference in the way Realism views promoting the interest of the state and intervention; and how humanitarian intervention is being viewed in this article. The humanitarian intervention, a subset of the interest-driven interventions that Realism sanctions, is driven by humanitarian transgressions in the intervened state due to which an unacceptable consequence accrues to the intervening state.

To better understand this position, one needs to briefly look at Realism more closely. Realism as a theory of IR emerged after the Second World War from the work of Edward Hallett Carr. ${ }^{25}$ Carr's position was developed further by Morgenthau, who is regarded by many as the its founder. ${ }^{26}$ After its emergence, this school of thought became the dominant theory in IR for the greater part of the Twentieth Century. ${ }^{27}$ Realists trace the historical support for their thinking all the way back to the time of the Greek city-states and the Peloponnesian War. Its core elements can be identified as statism, survival and self-help. ${ }^{28}$ Statism means that the state is the main actor in international relations; and operates in an international system of anarchy, which is different from the ordered sphere of domestic politics. Thus, Realism implicitly proposes a normative position, which is that states must pursue their national interest and must maximise their own power, particularly military power for survival. ${ }^{29}$ They can either amass power by themselves or can attain power by forming alliances. State survival and stability in the international system comes from a balance of power in the international relations of a state. According to Morgenthau 'international politics, like all politics, is a struggle for power. ${ }^{30}$

25 Edward. H. Carr, The Twenty Years' Crisis: 1919-1939: An Introduction to the Study of International Relations, 2nd ed. (New York: Palgrave Macmillan, 1946).

${ }^{26}$ Ariel Colonomos, Moralizing International Relations: Called to Account, Series in International Relations and Political Economy (New York: Palgrave Macmillan, 2008), 33.

${ }^{27}$ Tim Dunne and Brian C. Schmidt, "Realism," in The Globalization of World Politics: An Introduction to International Relations, 2nd ed., eds. John Baylis and Steve Smith (Oxford: Oxford University Press, 2001), 141.

28 Ibid., 36.

${ }^{29}$ Colonomos, Moralizing International Relations: Called to Account, 37.

${ }^{30}$ Morgenthau, Politics among Nations: The Struggle for Power and Peace, 13. 
Realism does, however, acknowledge a dual moral standard where there exists a domestic moral standard, but in the international context, morality does not apply. ${ }^{31}$ The attitude that morality is primarily a domestic issue, and that beyond national borders, there is little morality is an important reason why the ethical is so inadequately addressed in international relations. ${ }^{32}$ There is a difference in the position of Realist theorising, and its adherents, and the way the concept of state interest and its pursuit as being used in this article. The difference here is that the state is intervening to address a humanitarian situation in another country because the humanitarian condition is affecting the interest of the state that is intervening. Realist thinking, on the other hand, is focused on power maximisation and the humanitarian situation becomes, at best, incidental or, at worst, inconsequential to the intervention that is being undertaken.

\section{Intervening States and Humanitarian Aspect: Case of Bangladesh and China}

Examination of how the humanitarian injustices, being perpetuated in Naypyidaw, influence the interest of the international state actors requires looking at the latter in the international relations of Myanmar, especially those that share borders with it, namely, Bangladesh and China. The article also briefly looks at the interests of other states, like India in the broader context of terrorism which has a possible global scope.

\section{Bangladesh}

The common border with Rakhine region makes Bangladesh a viable option for the Rohingya refugees. There are also cultural affinities between them and segments of the Bangladeshi population. ${ }^{33}$ In the past, several major movements of refugees took place from Myanmar to this

31 Dunne and Schmidt, "Realism," 143.

${ }^{32}$ Mark Gibney, "Ethics and Refugees," in Ethics and International Affairs: Extent and Limits, ed. Jean-Marc Coicaud and Daniel Warner (Tokyo: United Nations University Press, 2001), 219.

${ }^{33}$ Coclanis, "Terror in Burma: Buddhist vs. Muslims," 30. 
country: in 1978 where an estimated 200,000 Rohingya fled; and another in 1991 with over 200,000 refugees. ${ }^{34}$ Displacement in such large numbers threatens the stability of Bangladesh and poses a security challenge for this state. A humanitarian intervention that helps resolve the internal issues faced by the Rohingya fits the case of Bangladesh because the crisis is very directly fuelling refugee influx affecting its economy, security and regional interests. ${ }^{35}$

\section{China}

China's relationship with Myanmar is more complicated. ${ }^{36}$ Beijing has invaded Burma several times and destroyed then-capital Pagan in the Thirteenth Century. Myanmar was a tributary state of China till the Nineteenth Century. From the 1980s, the country further developed its trade and investment ties, sale of military armaments from Beijing, which also vetoed the UN resolutions that sought to pressure the country on its human rights violations.

China shares a border of over 2000 kilometers with Myanmar. In addition, Myanmar provides Beijing access to the Indian Ocean. This access has both economic and security implications. A Myanmar allied with China can also be a source of exerting pressure on India's eastern flank. The term Pauk-Phaw, in the Burmese language means 'kinsfolk' - a term used by both to describe their relationship. ${ }^{37}$ The fact that China's economic development might help spur development in Myanmar is a powerful incentive for both countries to support each other. For example,

\footnotetext{
${ }^{34}$ Syeda Naushin Parnini, "The Crisis of the Rohingya as a Muslim Minority in Myanmar and Bilateral Relations with Bangladesh," Journal of Muslim Minority Affairs 33, no. 2 (2013): 281-297 (281), https://doi.org/10.1080/13602004.2013.826453.

${ }^{35}$ Utpala Rahman, "The Rohingya Refugee: A Security Dilemma for Bangladesh," Journal of Immigrant and Refugee Studies 8, no. 2 (2010): 233-239, https://doi.org/10.1080/15562941003792135.

36 J. Mohan Malik, "Myanmar's Role in Regional Security: Pawn or Pivot?" Contemporary Southeast Asia: A Journal of International and Strategic Affairs 19, no. 1 (1997): 52-73.

${ }^{37}$ Ricky W. Yue, "Sino-Myanmar Relations: Is Pauk-Phaw Pragmatic or Rhetoric," Journal of Comparative Asian Development 13, no. 2 (2014): 264-289 (264).
} 
Myanmar is supportive of the One Belt-One Road (OBOR) initiative. ${ }^{38}$ It has abundant natural resources, such as gas, and Beijing can help in their development and sale.

Some regional experts posit that the relations between Myanmar and China are strained by its suspicions of the Middle Kingdom, and this view is based on the premise that Myanmar wants to be careful in ensuring that it maintains its independence and sovereignty. ${ }^{39}$ This desire can be seen in the country's recent policy towards both China and India. While China has been allowed to build railway tracks and pipelines from Yunnan to the Arakan coast, India has also been given permission to build a port on the same coastline. ${ }^{40}$ India sees the importance of Myanmar as a way to possibly block Beijing's access to the Indian Ocean and restricting the economic and strategic benefits that accrue due to such access. The US is also concerned about the relationship between Myanmar and China.

However, the benefit for China in a possible intervention in Myanmar is much more complicated and nuanced than the position of Bangladesh. The Chinese are already involved in Myanmar and the involvement of the US and India, to a lesser extent, means that Beijing has to be careful to not push Myanmar towards either. To consolidate its position, China needs to pursue a policy that is viewed as friendly by the regime in Myanmar. This policy is more likely to be uncritical support for the regime and restricted criticism on humanitarian grounds. Though, China has taken on a mediatory role in attempts at engineering peace between the different factions and the government in peace talks held in 2016 and $2017,{ }^{41}$ on the basis of what has been discussed, there does not appear to be an interest-driven thrust for Beijing to intervene in Myanmar, given the geopolitics of the region and its relationship with the

\footnotetext{
38 Jonathan T. Chow and Leif-Eric Easley, "Myanmar's Foreign Policy Rebalance," Diplomat, September 10, 2016, https://thediplomat.com/2016/09/myanmars-foreignpolicy-rebalance/.

39 Andrew Selth, "Burma, China and the Myth of Military Bases," Asian Security 13, no. 3, (2007): 279-307 (285), https://doi.org/10.1080/14799850701568929.

${ }^{40}$ Prem Mahadevan, "The Changing Politics and Geopolitics of Burma," Strategic Analysis 37, no. 5 (2013): 596-609 (605),

https://doi.org/10.1080/09700161.2013.821248.

${ }^{41}$ Bertil Lintner, "China Captures Myanmar's Peace Process," Asia News, June 3, 2017.
} 
government in Naypyidaw. One needs to also be mindful of China's own history that makes it highly suspicious of foreign interventions, for understandable reasons. While not a part of this case study, India's position on the Rohingya issue, in particular under Modi and the Bharatiya Janata Party's influence, also rests on the side of the regime rather than the victims. The US does not see the subject as a priority either.

With China mainly following a realist foreign policy, and the other two important powers uninterested in the issue, a possible intervention is difficult to imagine in practice. However, in addition to the specific interests of these relevant states that border Myanmar, there is also an aspect of the humanitarian intervention that relates to the interests of the wider community of states. This interest is invoked if the extreme suffering of the Muslim Rohingya contributes to a greater propensity for some of them towards radicalisation and possible terrorism. Curbing possible future terrorism from among this suffering population provides a basis for benefitting the international community, and thus, may provide a rationale for humanitarian intervention in Myanmar. The violence against the Muslims has been labelled by some as 'Buddhist terror' ${ }^{42}$ and such extremes of violence are fertile grounds for fuelling a reaction that involves religious difference. Nobel Peace Prize winner Muhammad Yunus in a Foreword to Azeem Ibrahim's book writes that if this extreme persecution of the Rohingya people continues, it leaves open the possibility of future radicalisation of this population. ${ }^{43}$ And although a peaceful settlement is the more suitable path, there is a segment, albeit much smaller, within Muslim countries, that supports measures other than those that are peaceful. ${ }^{44}$

The threat from terrorism is taking on added importance because of a variety of factors, including, the continued violence against the

${ }^{42}$ Coclanis "Terror in Burma: Buddhist vs. Muslims," 28.

${ }^{43}$ Ibrahim, The Rohingyas: Inside Myanmar's Hidden Genocide, xiii-xiv.

${ }^{44}$ Iftekharul Bashar, "Exploitation of the Rohingya Crisis by Jihadist Groups Implications for Bangladesh's Internal Security," Counter Terrorist Trends and Analysis 9, no. 9 (2017): 5-7 (5-6), https://www.rsis.edu.sg/wp-content/uploads/2017/09/CTTASeptember-2017.pdf. 
Rohingya and non-state actors (NSAs) such as the Islamic State and alQaeda. The threat is also magnified given the increasing use of new media technologies in recent years in Myanmar, ${ }^{45}$ and how these technologies can facilitate contacts between the Rohingya and radical terrorist networks. Their plight has already attracted the attention of religiously motivated extremist groups and organisations; and has even motivated attempts at violence, such as the one against Myanmar's embassy in Jakarta; ${ }^{46}$ and some calls for armed jihad (holy war) against the government. $^{47}$

Persecution and violence against the Rohingya resulting in future acts of terrorism may have a greater impact in China than other countries of the world. China has also used its position as a permanent member of the United Nations Security Council (UNSC) to veto efforts to involve the international community in taking actions against Myanmar, such as in 2007. Further, Beijing has been facing criticism recently for its treatment of minorities, especially, the Uyghur Muslims in Xinjiang. ${ }^{48}$ So, while it may be following the realist paradigm, these factors make it more likely than other countries to be affected by radicalisation near its border, and possible future terrorism by a section of the persecuted Rohingya population.

\section{Intervened State and the Humanitarian Aspect}

A major moral justification for humanitarian intervention is the benefit that will accrue to the population in the intervened state. The Rohingya community in Myanmar has been subjected to extreme human rights

45 Laura Steckman, "Myanmar at the Crossroads: The Shadow of Jihadist Extremism," Counter Terrorist Trends and Analyses 7, no. 4 (2015): 10-16 (11).

${ }^{46}$ Iftekharul Bashar "Jihadists at the Gate? A Preliminary Enquiry into the Reaction of the Jihadist Movement to Communal Violence in Myanmar," Counter Terrorist Trends and Analysis 5, no. 6 (2013): 14-16 (14), https://www.rsis.edu.sg/wpcontent/uploads/2014/09/CTTA-June13.pdf.

${ }^{47}$ Ibid., 16.

${ }^{48}$ Simon Tisdall, "China's Pitiless War on Muslim Uighurs Poses a Dilemma for the West," Guardian, September 15, 2018, https://www.theguardian.com/world/2018/sep/15/china-pitiless-war-on-muslim-uighursposes-dilemma-for-the-west. 
violations for an extended period. The government does not seem to have great interest in alleviating their suffering. Their stateless status confirms the government's intention to forcefully exclude them from availing state mechanisms for redressing their grievances and injustices. Their political and civic exclusion is further consolidated with invoking differences on accounts of race, religion and culture. Though, there are several communities that live in Myanmar, and in divisive societies, the benefit of one community may be seen as a loss by others. However, one thing is clear, the Rohingya are suffering disproportionally and to a very great extent in comparison to other population groups in Myanmar.

The lack of citizenship or nationality structures extreme forms of exclusion by presenting obstacles to participation in the political process, ineligibility to vote, restrictions on employment, an inability to access public services such as medical and health, education, and an inequality before the law, among others. But the lack of nationality is exacerbated if an ethnic or racial difference is part of the reasons for denying nationality. ${ }^{49}$

The moral force of the argument that the Rohingya are facing a humanitarian situation of extreme proportions gained strength after publishing of the 'Report of the Detailed Findings of the Independent International Fact-Finding Mission on Myanmar' in September 2018 by the UN Human Rights Council. This 400-plus page report clearly states that the actions of the Myanmar Government shows 'consistent patterns of human rights violations' and recommends that some named senior government officials be 'investigated and prosecuted in an international criminal tribunal for genocide, crimes against humanity and war crimes. ${ }^{50}$ This report lends credence for humanitarian intervention at the earliest to

\footnotetext{
${ }^{49}$ Indira Goris, Julia Harrington, and Sebastian Köhn, "Statelessness: What it is and Why it Matters?" Forced Migration Review, no. 32 (2009): 4-6, https://www.fmreview.org/sites/fmr/files/FMRdownloads/en/FMRpdfs/FMR32/FMR32. pdf.

${ }^{50} \mathrm{HRC}$, The Detailed Findings of the Independent International Fact-Finding Mission on Myanmar, report (Geneva: United Nations Human Rights Council, 2018), https://www.ohchr.org/Documents/HRBodies/HRCouncil/FFMMyanmar/A_HRC_39_CRP.2.pdf.
} 
Imran Syed

ameliorate the suffering and protect the interests of the Rohingya of Myanmar.

\section{Conclusion}

Drawing on aspects of IR and global ethics, this article takes a look at a possible structure for examining international humanitarian intervention and then applies this structure to address the issues faced by the Rohingya of Myanmar. The idea that intervention can move beyond primarily the theoretical if, as shown here, support for a humanitarian intervention is structured around the possible benefits of the intervening state and the benefits to the population suffering in the state being intervened into. The moral position that the interest of peoples within the intervened state, in the face of extreme persecution and violence, provides a justification for humanitarian intervention needs to be looked at carefully. A detractor of this moral positioning may be that Myanmar is a highly diverse country and the contention between the Rohingya minority and the Buddhist majority places the two communities in competition with each other. Therefore, for some, any benefit to this community can be seen as a loss to the Buddhist majority. Addressing this dilemma requires recognising the UN verified extremes of suffering and violence that are being perpetrated on the Rohingya - including forced displacement, rape, and genocide - and that such extremes of violence can never be justified against benefit that is accruing to any other group within Myanmar.

The two states that are most closely involved with Myanmar: Bangladesh and China, stand to benefit from a resolution of the Rohingya issue. China is a major power in the region and the existing support it has in Myanmar makes a forced intervention possibly not very beneficial in the short-term for the Republic as its economic and geostrategic interests are contingent on a good relationship with the present government in Myanmar. However, this does not mean that China can ignore the humanitarian crisis that is happening in Rakhine region, and not directly face any long-term negative consequences. The threat that China may face is from a possible radicalisation of a section of the persecuted Rohingya population. This situation will impact it more adversely than other 
To Intervene or Not to Intervene: Ethics of Humanitarian Intervention in Myanmar

countries, precisely because of its substantial support to the Myanmar government. It has also restricted international multilateral action against the government, and is seen as mistreating its own Muslim population. This article recommends that a potential solution, that incorporates the ethics of humanitarian intervention can lead to China and Bangladesh working together, alongside the political structure that exists in Myanmar, to address this crisis. China has already taken steps in this direction, but there needs to be a more deliberate involvement that focuses on actually engineering a solution.

To a less impactful extent, the efforts of both countries need to be supplemented by the international community so that the potential for terrorism gaining a stronghold among the disposed Rohingya does not develop. The justification posed by an extrapolation of the present scenario to future extremist terrorism, positions the potential for possible imminent harm from the latter against the historically established norm of international non-intervention. The motivation for proactive action now rather than waiting for the terrorism to get entrenched is that once it is entrenched, rectifying the situation will be much more difficult. 